\title{
Keaktifan Siswa pada Penerapan Penggunaan Media Pembelajaran Papan Rotasi (Partasi) Materi Transformasi Geometri
}

\author{
${ }^{1}$ Chusnul Ma'rifah, ${ }^{2}$ Abd Qohar \\ ${ }^{1}$ MAN 3 Malang, Indonesia \\ ${ }^{2}$ Jurusan Matematika FMIPA Universitas Negeri Malang, Indonesia \\ Email: 1'chusnulmarifah85@gmail.com, ${ }^{2}$ abd.qohar.fmipa@um.ac.id
}

\section{Tersedia Online di \\ http://www.jurnal.unublitar.ac.id/ index.php/briliant}

\begin{tabular}{l}
\hline Sejarah Artikel \\
\hline Diterima pada 26 Juli 2020 \\
Disetujui pada 23 Oktober 2020 \\
Dipublikasikan pada 30 \\
November 2020 \\
Hal. 698-709 \\
\hline
\end{tabular}

\section{Kata Kunci:}

Media partasi; Rotasi; Keaktifan

Siswa

\section{DOI:}

http://dx.doi.org/10.28926/briliant .v3i4.525

\begin{abstract}
Abstrak: Media pembelajaran dengan papan rotasi merupakan salah satu media yang telah dikembangkan. Menurut hasil uji coba yang telah dilakukan, media papan rotasi (partasi) banyak membantu siswa dalam meningkatkan pemahaman konsep. Penelitian ini bertujuan untuk memperoleh informasi yang mendeskripsikan keaktifan siswa dengan adanya penerapan media partasi dalam pembelajaran transformasi geometri khususnya bahasan rotasi. Jenis penelitian ini adalah penelitian deskriptif kualitatif. Analisis yang dilakukan oleh peneliti memperoleh hasil bahwa keaktifan siswa dalam katagori tinggi dengan persentase 90, 93\%. Keaktifan itu ditunjukkan dengan keseriusan siswa dalam melakukan percobaan menggunakan media partasi dan berdiskusi kelompok hingga dapat menemukan rumus rotasi.
\end{abstract}

\section{PENDAHULUAN}

Proses belajar mengajar matematika masih sering terjadi permasalahan yang disebabkan oleh pembelajaran yang belum efektif dan efisien (Putri, Candiasa, dan Suweken; 2016). Salah satu penyebabnya adalah kurangnya ketertarikan siswa pada matematika dan stigma sulit yang masih melekat. Hal ini sejalan dengan hasil wawancara dengan Bu Umi Faizah, S.Pd selaku guru mata pelajaran matematika d MA Miftahul Huda kepanjen Malang, bahwa penyebab pembelajaran matematika kurang efektif adalah dikarenakan minat dan semangat siswa cenderung rendah dalam belajar matematika. Sedangkan menurut wawancara dengan salah satu siswa, alasan pelajaran matematika kurang diminati adalah karena banyak materi pelajaran matematika yang sulit untuk dimengerti dan materi yang dipahami cenderung abstrak. Siswa memahami pelajaran hanya menghafalkan rumus dan siswa hanya bisa membayangkan objek yang abstrak pada materi tertentu.

Salah satu materi yang menuntut siswa untuk berpikir abstrak, yaitu transformasi geometri yang terdapat pada jenjang menengah atas. Ada empat jenis transformasi, yaitu translasi, rotasi, refleksi dan dilatasi. Pada materi transformasi geometri ini siswa harus dapat membayangkan bagaimana suatu objek 
transformasi ditinjau dari posisi dan bentuk, baik pada objek awal maupun objek bayangan. Objek transformasi dapat berupa titik, garis dan bangun datar.

Banyak siswa yang masih mempelajari materi geometri dengan memperhatikan gambar di buku ataupun papan tulis pada kenyataannya. Guru juga hanya menjelaskan seadanya tanpa memperhatikan aspek kebutuhan abstraksi siswa dalam mempelajari materi geometri ini. Karena sebab inilah, tidak mengherankan apabila banyak siswa yang merasa kesulitan dalam memahami materi geometri khususnya transformasi geometri.

Apa yang terjadi di atas sejalan dengan yang diungkapkan oleh Sutiarso\&Coesamin (2018) bahwa tingkat kesulitan belajar geometri jauh lebih sulit daripada aljabar dan statistik. Kesalahpahaman geometri mencakup dua aspek, yaitu konseptual dan prosedural. Kesalahpahaman konseptual yaitu kesalahan dalam mengidentifikasi objek dan mengaitkan hubungan matematika dengn objek tersebut, sedangkan kesalahpahaman prosedural adalah kesalahan dalam penggunaan simbol, aturan, dan algoritme untuk menyelesaikan masalah (Sutiarso and Coesamin 2018).

Berdasar kesulitan di atas, maka guru haruslah mempunyai inisiatif dan langkah yang tepat agar siswa tidak memgalami kesulitan konseptual dan prosedural. Hal ini dapat dilakukan guru dengan mendorong siswa untuk aktif belajar serta siswa diberikan pengalaman belajar yang memadai. Untuk mendukung hal ini, maka dalam pembelajaran diperlukan suatu media pembelajaran agar siswa dapat melakukan pembelajaran dengan aktif sehingga terbentuk interaksi serta pengalaman belajar yang baik, mengingat pembelajaran dengan media sudah dianggap penting (Kabha, 2019).

Menurut Hamalik (2008) keaktifan belajar diartikan suatu keadaaan dimana siswa dapat berbuat aktif. Keaktifan tersebut dapat dilihat dari keterlibatan mereka dalam berbagai proses pembelajaran, seperti mendengarkan penjelasan materi, berdiskusi, membuat laporan tugas dan sebagainya. Ciri keaktifan belajar siswa menurut Sudjana (2010) dapat dilihat dalam: 1) turut serta dalam melaksanakan tugas belajar, 2) terlibat dalam pemecahan masalah, 3) bertanya apabila tidak memahami persoalan yang dihadapinya, 4) mencari informasi untuk memecahkan masalah, 5) melakukan diskusi kelompok sesuai dengan petunjuk guru, 6) memulai kemampuan dirinya dan hasil-hasil yang diperoleh, 7) melatih dirinya dalam memecahkan soal atau masalah yang sejenis, 8) kesempatan menggunakan atau menerapkan apa yang telah diperoleh dalam menyelesaikan tugas atau persoalan yang dihadapinya

Indikator keaktifan siswa yang lain dijelaskan oleh Dimyati dan Mudjiono (Fatkhan, 2018). Siswa dapat dikatakan aktif ketika: 1) mencatat atau mendengarkan penjelasan guru, 2) memperhatikan materi yang dijelaskan guru, 3) mencatat tugas dan mengerjakan tugas rumah yang diberikan, 4) berdiskusi dalam kelompok untuk memecahkan masalah yang berkaitan dengan pelajaran, 5) melibatkan diri dalam tanya jawab, 6) menyimpulkan pembelajaran bersama guru dan siswa lainnya.

Sejalan dengan indikator keaktifan siswa di atas, terdapat enam hal yang mempengaruhi keaktifan siswa dikelas (Wibowo, 2016). Enam hal tersebut adalah siswa, guru, materi, tempat, waktu, dan fasilitas. Peran guru dibutuhkan dalam aktifitas di kelas, karena semua bentuk kegiatan pembelajaran di kelas diatur oleh guru. Aktifitas di kelas dapat diatur guru sesuai dengan tujuan pembelajaran. 
Dengan kata lain keaktifan siswa membuat pembelajaran berjalan sesuai dengan perencanaan pembelajaran yang telah disusun guru. Bentuk aktifitas siswa dapat berbentuk aktifitas pada dirinya sendiri atau aktifitas dalam suatu kelompok (Wibowo 2016).

Berdasarkan paparan di atas, maka proses pembelajaran matematika khususnya transformasi geometri hendaknya dapat menggunakan media pembelajaran yang mendukung pembelajaran tersebut. Media pembelajaran tersebut diharap berfungsi sebagai wahana untuk membelajarkan konsep ataupun pesan pembelajaran pada siswa. Media pada proses belajar-mengajar diharapkan dapat membantu guru dalam meningkatkan pemahaman belajar siswa sehingga siswa menjadi lebih aktif dan pembelajaran menjadi lebih bermakna.

Media pembelajaran telah menjadi satu kesatuan dalam pembelajaran yang terintegrasi, bahkan tidak bisa dipisahkan dalam proses pembelajaran di sekolah (Setyorini and Churiyah 2016). Walter Mc Kenzie (Musfiqon, 2012) menyatakan bahwa media memiliki peran penting dalam pembelajaran di kelas yang dapat mempengaruhi kualitas dan keberhasilan pembelajaran. Hal ini dikarenakan media pembelajaran adalah alat untuk mengimplementasikan proses yang memungkinkan pendidik dan peserta didik untuk melakukan kegiatan belajar (Widodo 2018).

Optimalisasi dalam penggunaan media dalam pembelajaran dapat mendorong tercapainya hasil belajar yang lebih optimal. Guru dan siswa dapat belajar berdampingan langsung dan menguasai materi dengan bantuan media yang telah disesuaikan dengan isi dan tujuan pembelajaran (Arsyad 2005). Penggunaan media pada tahap orientasi pembelajaran juga akan sangat membantu keefektifan dan penyampaian pesan dan isi pembelajaran saat itu. Selain untuk membangkitkan motivasi dan minat siswa, media pembelajaran juga dapat membantu siswa meningkatkan pemahaman, menyajikan data dengan menarik dan terpercaya, memudahkan menafsir data dan mendapatkan informasi.

Salah satu media yang dapat digunakan untuk mengembangkan media pembelajaran transformasi geomateri adalah papan rotasi (partasi). Papan rotasi (partasi) adalah papan pembelajaran yang dibuat dalam pelajaran matematika sebagai media pembelajaran pada bahasan rotasi. Papan rotasi ini dapat dimanfaatkan untuk meningkatkan pemahaman siswa dengan mengkonstruksi bagaimana rumus rotasi diperoleh melalui berbagai macam percobaan. Dengan menggunakan papan rotasi, diharapkan keaktifan siswa dapat meningkat sehingga mendapatkan pembelajaran yang interaktif dan eksploratif sehingga dapat membantu siswa dalam memahami materi rotasi. Misalnya suatu titik dirotasikan sejah $90^{\circ}$, maka dengan menggunakan papan rotasi siswa dapat melihat bayangan objek hasil rotasi. Begitu juga seterusnya dengan berbagai sudut yang beragam.

Berdasarkan latar belakang di atas, maka diperoleh rumusan masalah bagaimana keaktifan siswa saat pembelajaran dengan menggunakan media partasi pada bahasan rotasi. Adapun dari penelitian ini adalah untuk mendeskripsikan bagaimana keaktifan siswa ketika mempelajari materi rotasi dengan menggunakan media pembelajaran partasi.

\section{METODE}

Jenis penelitian ini adalah penelitian lapangan dengan pendekatan kualitatif (Creswell 2012) dan bersifat deskriptif yang bertujuan mendeskripsikan

700 BRILIANT: Jurnal Riset dan Konseptual Volume 5 Nomor 4, November 2020 
keaktifan siswa MA Miftahul Huda kepanjen Malang ketika belajar materi rotasi dengan menggunakan media pembelajaran partasi. Media partasi yang digunakan dapat dilihat pada gambar di bawah ini.
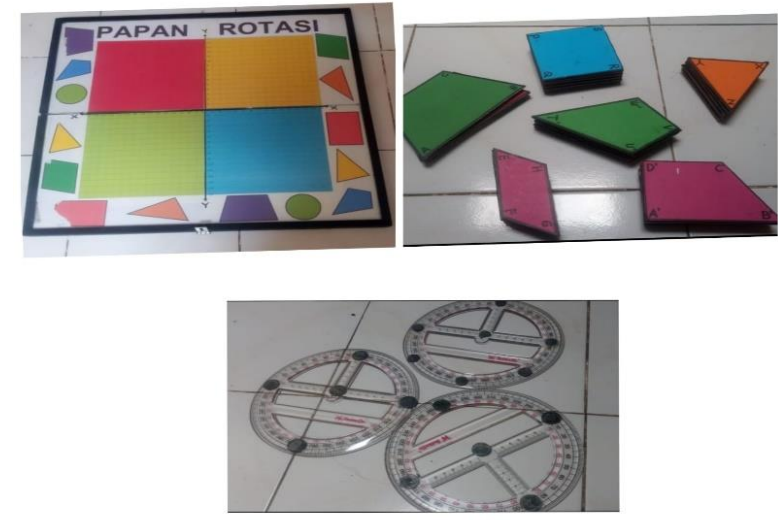

Gambar1. Media Partasi dan Komponennya

Media partasi pada gambar 1 di atas merupakan media pembelajaran yang terbuat dari kayu dan berupa papan koordinat kartesius yang dilengkapi dengan empat kudran. Komponen lain adalah busur berukuran $360^{\circ}$ yang dipasang pada pusat koordinat $(0,0)$ dan beberapa bangun datar yang dilengkapi dengan nama titik pojok. Titik-titik pada bangun datar inilah yang akan dirotasikan dengan berbagai ukuran sudut lalu dicari posisi bayangan titiknya. Siswa dapat mencari rumus umum rotasi titik pada berbagai sudut dengan cara menggeneralisasi hubungan antara koordinat titik awal dan koordinat bayangan titik yang dihasilkan.

Subjek penelitian adalah siswa kelas XI IPA MA Miftahul Huda Kepanjen Malang yang berjumlah 19 siswa. Siswa sejumlah 19 anak ini selanjutnya akan dibentuk kelompok dengan empat atau lima siswa pada setiap kelompoknya dan diberikan satu media partasi.

Prosedur penelitian dalam penelitian ini yaitu 1) penyusunan instrumen penelitian, 2) pelaksanaan penelitian, dan 3) analisis data. Data penelitian yang akan diperoleh yaitu 1) observasi keaktifan siswa dalam penerapan media pembelajaran partasi, 2) hasil angket tentang penerapan media partasi, dan 3) wawancara mengenai respon siswa terhadap pembelajaran dengan menggunakan media partasi. Metode pengumpulan data yang dilakukan dengan wawancara, observasi, dan dokumentasi.

Teknik yang dilakukan adalah 1) observer mengamati dan mengisi lembar observasi keaktifan siswa selama pembelajaran berlangsung, 2) observer mengamati hasil kerja siswa dalam Lembar Kerja Peserta Didik (LKPD), dan 3) siswa mengisi angket dan mengikuti wawancara untuk memberikan tanggapan terhadap penerapan media partasi. Instrumen yang digunakan adalah: 1) lembar observasi keaktifan siswa, 2) lembar kerja peserta didik secara kelompok, dan (3) lembar angket. Ketiga instrument ini telah divalidasi oleh satu dosen matematika dan dua orang guru matematika.

Analisis data dilakukan dengan melakukan analisis kegiatan pembelajaran terhadap: 1) data hasil observasi yang membantu peneliti untuk mengetahui keaktifan siswa ketika pembelajaran dengan menggunakan partasi dengan indkator yang ditetapkan; 2) lembar kerja peserta didik sebagai observasi wujud 
keaktifan siswa; (3) angket untuk mengetahui respon siswa terhadap pembelajaran dengan menggunakan media papan partasi yang diperkuat dengan wawancara.

Indikator keaktifan siswa dengan yang diobservasi dalam penelitian ini yaitu: (1) mengajukan pertanyaan kepada guru, (2) menjawab pertanyaan guru, (3) melakukan percobaan rotasi titik, (4) mengamati percobaan rotasi titik, (5) menggunakan media, (6) menuliskan jawaban pada LKPD, (7) diskusi dalam kelompok, (8) bekerjasama dalam kelompok, (9) mengamati kegiatan presentasi, (10) mendengarkan sajian presentasi, (11) mengemukakan pendapat, dan (12) mendengarkan penjelasan/informasi guru. Penilaian pada lembar observasi dengan indikator ini adalah dengan menentukan persentase keaktifan siswa selama pembelajaran dari masing-masing indikator. Adapun rumus yang digunakan mengacu pada Wijayanti (dalam Suseno dkk, 2017) adalah:

$$
\text { Capaian }=\frac{\text { jumlah skor yang diperoleh }}{\text { Jumlah skor maksimun }} \times 100 \%
$$

Indikator keberhasilan dari keaktifan siswa (Suseno, dkk, 2017) dapat dilihat pada tabel berikut.

Tabel 1. Kriteria Hasil Persentase pada Keaktifan

\begin{tabular}{ll}
\hline Capaian & Kriteria \\
\hline $75 \%-100 \%$ & Tinggi \\
$51 \%-74 \%$ & Sedang \\
$25 \%-50 \%$ & Rendah \\
$<25 \%$ & Sangat Rendah \\
\hline
\end{tabular}

Setelah dilakukan pembelajaran dengan media partasi, angket diberikan untuk mengetahui respon siswa. Aspek yang ditanyakan dalam angket antara lain yaitu: (1) media partasi mudah digunakan, (2) penyajian masalah pada media partasi membantu siswa dalam memahami konsep matematika, (3) senang belajar matematika melalui media partasi karena menarik, (4) media partasi membuat menyukai matematika, (5) Media partasi membuat siswa ingin memahami matematika lebih lanjut, (6) petunjuk dan informasi yang disajikan mudah dipahami dan (7) tampilan media pembelajaran menarik. Respon siswa dalam angket terhadap pembelajaran dengan partasi hitung dengan rumus sebagai berikut (Purnomo 2015):

\begin{tabular}{cl} 
Rumus & \multicolumn{1}{c}{ Keterangan } \\
$S P=\frac{S A}{S M} \times 100$ & $\begin{array}{l}\text { SA }=\text { Skor Akhir } \\
\text { SP }=\text { Skor Perolehan } \\
\text { SM }=\text { Skor Maksimal }\end{array}$ \\
\hline
\end{tabular}

Untuk mengetahui apakah siswa tersebut mempunyai respon rendah atau tinggi terhadap penerapan pembelajaran menggunakan media partasi, dapat dilihat dari kriteria skor akhir angket pada tabel dibawah ini (Purnomo 2015):

Tabel 2. Kriteria Skor pada Angket

\begin{tabular}{ll}
\hline Rentang Skor Akhir (Persentase) & Kriteria Skor \\
\hline $51-100$ & Tinggi \\
$33-50$ & Rendah \\
\hline
\end{tabular}

702 BRILIANT: Jurnal Riset dan Konseptual Volume 5 Nomor 4, November 2020 


\section{HASIL}

Pelaksanaan penelitian dilaksanakan pada hari selasa, tanggal 3 Maret 2020 dengan satu kali pertemuan dengan partisipan sebanyak 19 siswa MA Miftahul Huda Kepanjen Malang. Berdasarkan observasi yang dilakukan, dengan pembelajaran ini siswa cenderung tertarik dengan adanya media, sehingga keaktifan mereka sangat baik. Siswa tidak segan untuk bertanya kepada peneliti selaku guru tentang hal-hal yang tidak dimengerti selama pembelajaran. Siswa pun dengan aktif dan tanpa malu-malu menjawab pertanyaan guru ketika berkeliling mengobservasi kerja mereka dalam kelompok.

Menurut siswa, meskipun pembelajaran menggunakan partasi ini masih pertama mereka lakukan, namun mereka semangat sekali selama diskusi dalam kelompok dan menggunakan media partasi. Siswa berantusias dengan berbagai percobaan pada bangun datar dan titik sebagai objek rotasi. Berikut diantara hasil jawaban siswa dalam mencoba semua semua titik dan bangun beserta hasil rotasinya.

3. Selanjutnya, lakukan langkah-langkah berikut:

$\checkmark$ Ambil bangun datar berbeda sebanyak dua rangkap yang ada pada meja kalian.

Letakkan pada papan petak lalu tentukan koordinat titik pada masingmasing sudut.

$\checkmark$ Bangun pertama letakkan tetap ditempat semula.

Lalu rotasikan bangun kedua dengan besar sudut rotasi sejauh $90^{\circ}, 180^{\circ}$, $270^{\circ}$, dan $360^{\circ}$.

Dapatkah kalian menentukan koordinat masing-masing titik pada setiap besar sudut rotasi?

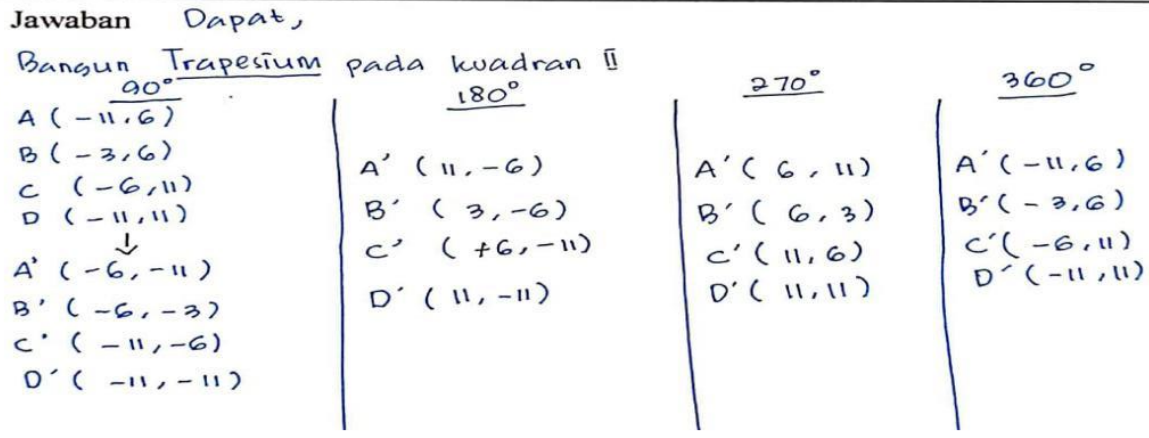

Gambar 2. Jawaban Siswa Mencari Bayangan Titik dengan Rotasi $90^{\circ}, 180^{\circ}, 270^{\circ}$ dan $360^{\circ}$ dari Suatu Titik

Diskusi dan kerjasama yang mereka lakukan sangatlah hidup. Guru selaku observer sekaligus peneliti terus mengamati jalannya diskusi hingga akhirnya mereka dapat mempresentasikan jawaban mereka masing-masing. Pada akhirnya, mereka dapat membuat kesimpulan bersama guru mengenai rumus rotasi titik dengan berbagai macam sudut. Berikut ini adalah kesimpulan rotasi dan rumus rotasi yang siswa temukan dari percobaan yang mereka lakukan dengan menggunakan media partasi. 
5. Berdasarkan hasil kerja kalian pada nomor 1 sampai dengan 4 , apa yang dapat kalian simpulkan mengenai rotasi pada titik?

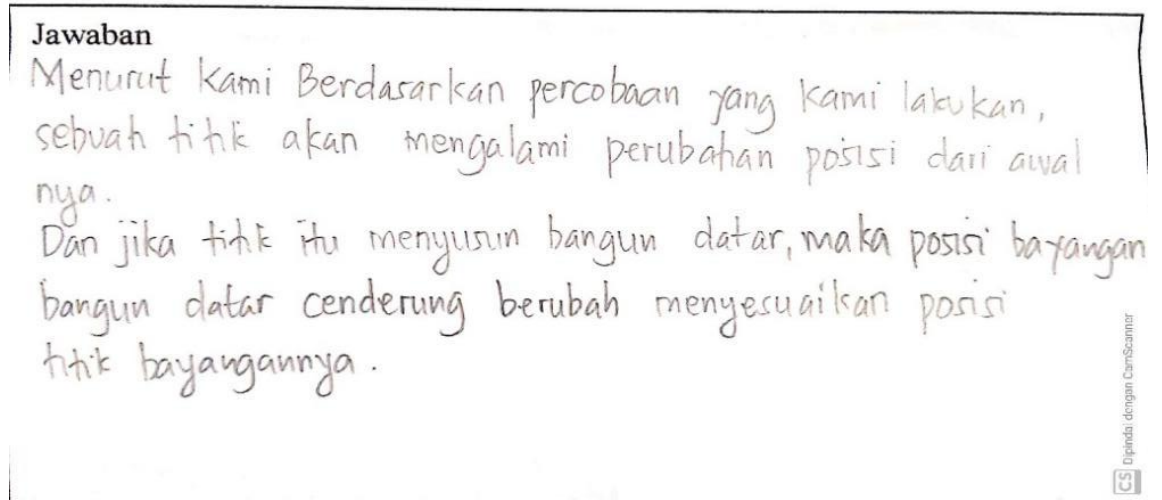

Gambar 3. Jawaban siswa menyimpulkan percobaan

\section{Kesimpulan Umum}

Untuk sembarang titik $\mathrm{A}(\mathrm{x}, \mathrm{y})$, maka hasil rotasi yang dihasilkan adalah

1. Rotasi $+90^{\circ}, A(x, y) \longrightarrow A(-y, x)$

2. Rotasi $+180^{\circ}, A(x, y) \longrightarrow A(-x,-y)$

3. Rotasi $+270^{\circ}, A(x, y) \longrightarrow A(. y,-\ldots)$

4. Rotasi $+360^{\circ}, A(x, y) \longrightarrow A(x, y)$

Sellammat Memgerjaukam

Gambar 4. Jawaban Siswa dalam Menyimpulkan Rumus Rotasi

Hasil observasi terhadap keaktifan siswa sangatlah bagus. Rata-rata capaian keaktifan siswa memperoleh nilai 90,93\%, yang artinya keaktifan siswa tinggi dalam pembelajaran menggunakan media partasi. Bentuk keaktifan tersebut dapat dilihat dari dokumentasi pada gambar berikut.
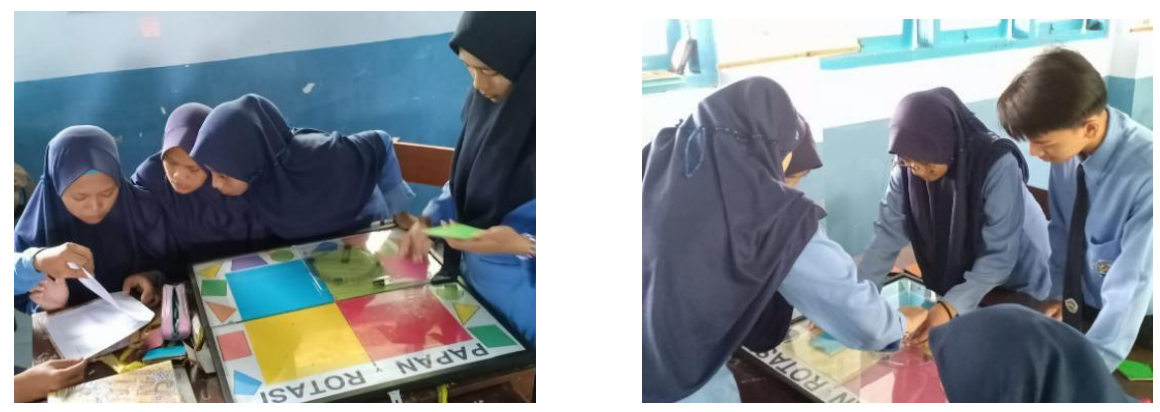

Gambar 5. Keaktifan siswa ketika menggunakan media pembelajaran partasi

Adapun perincian perolehan skor dari indikator keaktifan masing-masing siswa dapat dilihat pada tabel sebagai berikut. 
Tabel 3. Perolehan Skor dari Indikator Keaktifan

\begin{tabular}{|c|c|c|c|c|c|c|c|c|c|c|c|c|c|c|c|}
\hline \multirow[b]{2}{*}{ NO } & \multirow[t]{2}{*}{ Nama } & \multicolumn{12}{|c|}{ Skor Indikator ke- } & \multirow[t]{2}{*}{ Total } & \multirow[t]{2}{*}{ Nilai } \\
\hline & & 1 & 2 & 3 & 4 & 5 & 6 & 7 & 8 & 9 & 10 & 11 & 12 & & \\
\hline 1 & AGM & 3 & 3 & 3 & 3 & 3 & 3 & 3 & 3 & 3 & 3 & 3 & 3 & 36 & 100 \\
\hline 2 & AMM & 3 & 2 & 3 & 3 & 2 & 3 & 3 & 3 & 3 & 3 & 3 & 3 & 34 & 94 \\
\hline 3 & AR & 3 & 3 & 3 & 3 & 3 & 3 & 3 & 3 & 3 & 3 & 3 & 3 & 36 & 100 \\
\hline 4 & ARQ & 3 & 3 & 3 & 3 & 3 & 3 & 3 & 3 & 2 & 2 & 3 & 3 & 34 & 94 \\
\hline 5 & AMK & 3 & 3 & 3 & 3 & 3 & 3 & 3 & 3 & 2 & 3 & 3 & 3 & 35 & 97 \\
\hline 6 & $\mathrm{BU}$ & 3 & 3 & 3 & 3 & 3 & 3 & 3 & 3 & 2 & 3 & 3 & 3 & 35 & 97 \\
\hline 7 & FKA & 2 & 2 & 3 & 2 & 3 & 2 & 3 & 3 & 2 & 2 & 2 & 3 & 29 & 81 \\
\hline 8 & FS & 3 & 2 & 3 & 3 & 3 & 3 & 3 & 3 & 2 & 3 & 2 & 3 & 33 & 92 \\
\hline 9 & $\mathrm{HS}$ & 3 & 2 & 3 & 3 & 2 & 3 & 3 & 3 & 2 & 2 & 3 & 2 & 31 & 86 \\
\hline 10 & $\mathrm{HF}$ & 2 & 3 & 3 & 3 & 3 & 2 & 2 & 3 & 2 & 2 & 3 & 2 & 30 & 83 \\
\hline 11 & JA & 3 & 3 & 3 & 3 & 3 & 3 & 3 & 2 & 2 & 2 & 3 & 3 & 33 & 92 \\
\hline 12 & MS & 3 & 2 & 2 & 3 & 3 & 2 & 3 & 2 & 2 & 2 & 2 & 3 & 29 & 81 \\
\hline 13 & NNA & 3 & 3 & 3 & 3 & 3 & 3 & 3 & 3 & 2 & 2 & 3 & 3 & 34 & 94 \\
\hline 14 & PA & 3 & 3 & 3 & 3 & 3 & 3 & 3 & 3 & 2 & 3 & 3 & 3 & 35 & 97 \\
\hline 15 & RW & 3 & 3 & 3 & 3 & 3 & 3 & 3 & 2 & 2 & 3 & 2 & 3 & 33 & 92 \\
\hline 16 & $\mathrm{RP}$ & 2 & 2 & 3 & 2 & 2 & 3 & 3 & 3 & 2 & 2 & 2 & 3 & 29 & 81 \\
\hline 17 & SD & 2 & 2 & 3 & 3 & 3 & 3 & 3 & 3 & 3 & 3 & 2 & 3 & 33 & 92 \\
\hline 18 & SA & 2 & 2 & 3 & 3 & 3 & 3 & 3 & 3 & 2 & 2 & 2 & 3 & 31 & 86 \\
\hline 19 & UH & 3 & 2 & 3 & 3 & 3 & 2 & 3 & 3 & 2 & 2 & 2 & 3 & 31 & 86 \\
\hline
\end{tabular}

Dari tabel 3 di atas, dapat diketahui jika semua siswa telah memenuhi kriteria ketuntasan minimum keaktifan yang ditetapkan sekolah, yakni 75, sebab tidak ada siswa yang perolehan nilai keaktifannya di bawah 75 . Berdasarkan tabel 3 diatas, diperoleh capaian prosentase dari masing-masing indikator pada tabel 4 sebagai berikut:

Tabel 4. Prosentase Tiap Indikator Keaktifan

\begin{tabular}{llcc}
\hline No & \multicolumn{1}{c}{ Indikator } & Persentase & Kategori \\
\hline 1 & Mengajukan pertanyaan kepada guru & 91 & Tinggi \\
\hline 2 & Menjawab pertanyaan guru & 84 & Tinggi \\
\hline 3 & Melakukan percobaan rotasi titik & 98 & Tinggi \\
\hline 4 & Mengamati percobaan rotasi titik & 96 & Tinggi \\
\hline 5 & Menggunakan media & 95 & Tinggi \\
\hline 6 & Menuliskan jawaban pada LKPD & 93 & Tinggi \\
\hline 7 & Diskusi dengan kelompok & 98 & Tinggi \\
\hline 8 & Bekerjasama dalam kelompok & 95 & Tinggi \\
\hline 9 & Mengamati kegiatan presentasi & 74 & Sedang \\
\hline 10 & Mendengarkan sajian presentasi & 82 & Tinggi \\
\hline 11 & Mengemukakan pendapat & 86 & Tinggi \\
\hline 12 & Mendengarkan penjelasan/informasi guru & 96 & Tinggi \\
\hline
\end{tabular}

Dari perolehan tiap indikator di atas, diperoleh nilai tertinggi 98 yakni ketika siswa melakukan percobaan rotasi titik dan diskusi dengan kelompok. Sedangkan nilai yang paling rendah adalah 74 yakni pada saat siswa mengamati 
kegiatan presentasi. Hal ini dikarenakan siswa sangat asyik dalam melakukan percobaan menggunakan media partasi ketika diskusi, namun mereka kurang mempertimbangkan waktu yang ada. Bel pun berbunyi sebelum siswa dapat mempresentasikan semua hasil diskusi mereka, akhirnya siswa agak merasa resah karena waktu istirahat dan sholat dhuhur berjamaah akan segera dimulai. Namun hal ini dapat ditindaklanjuti dengan meminta ijin perpanjangan waktu untuk penelitian.

Setelah pelaksanaan pembelajaran dengan menggunakan media partasi selesai, angket kepada siswa dilaksanakan untuk mengetahui sejauh mana respon mereka terhadap pembelajaran. Angket yang diberikan memuat tujuh aspek. Adapun perolehan nilai dari angket yang diberikan dapat dilihat pada tabel berikut.

Tabel 4. Angket Penerapan Media Partasi

\begin{tabular}{|c|c|c|c|c|c|c|c|c|c|c|}
\hline \multirow[t]{2}{*}{ No } & \multirow[t]{2}{*}{ Nama } & \multicolumn{7}{|c|}{ Aspek ke- } & \multirow[t]{2}{*}{ Total } & \multirow[t]{2}{*}{ Nilai } \\
\hline & & 1 & 2 & 3 & 4 & 5 & 6 & 7 & & \\
\hline 1 & AGM & 4 & 4 & 4 & 4 & 4 & 4 & 4 & 28 & 100 \\
\hline 2 & AMM & 4 & 3 & 4 & 3 & 3 & 3 & 3 & 23 & 82 \\
\hline 3 & AR & 4 & 4 & 4 & 4 & 4 & 4 & 4 & 28 & 100 \\
\hline 4 & ARQ & 3 & 4 & 3 & 4 & 2 & 3 & 4 & 23 & 82 \\
\hline 5 & AMK & 4 & 4 & 3 & 3 & 3 & 3 & 4 & 24 & 86 \\
\hline 6 & $\mathrm{BU}$ & 4 & 4 & 4 & 4 & 3 & 3 & 4 & 26 & 93 \\
\hline 7 & FKA & 4 & 3 & 3 & 3 & 3 & 3 & 3 & 22 & 79 \\
\hline 8 & FS & 4 & 3 & 4 & 4 & 4 & 3 & 4 & 26 & 93 \\
\hline 9 & HS & 4 & 4 & 4 & 3 & 4 & 4 & 4 & 27 & 96 \\
\hline 10 & $\mathrm{HF}$ & 4 & 3 & 4 & 3 & 3 & 3 & 4 & 24 & 86 \\
\hline 11 & JA & 4 & 4 & 4 & 4 & 4 & 4 & 4 & 28 & 100 \\
\hline 12 & MS & 4 & 4 & 4 & 4 & 4 & 4 & 4 & 28 & 100 \\
\hline 13 & NNA & 4 & 3 & 4 & 3 & 3 & 4 & 4 & 25 & 89 \\
\hline 14 & $\mathrm{PA}$ & 4 & 3 & 4 & 3 & 3 & 4 & 4 & 25 & 89 \\
\hline 15 & RW & 3 & 4 & 4 & 3 & 4 & 4 & 4 & 26 & 93 \\
\hline 16 & $\mathrm{RP}$ & 4 & 3 & 4 & 3 & 4 & 4 & 4 & 26 & 93 \\
\hline 17 & SD & 4 & 4 & 4 & 3 & 3 & 4 & 4 & 26 & 93 \\
\hline 18 & SA & 3 & 4 & 4 & 4 & 3 & 4 & 4 & 26 & 93 \\
\hline 19 & $\mathrm{UH}$ & 4 & 3 & 3 & 4 & 4 & 4 & 4 & 26 & 93 \\
\hline \multicolumn{2}{|c|}{ Rata-rata } & $\begin{array}{c}3,8 \\
4\end{array}$ & 3,58 & 3,79 & 3,47 & 3,42 & 3,63 & 3,89 & 25,63 & 91,54 \\
\hline
\end{tabular}

Berdasarkan perhitungan di atas diperoleh rata-rata nilai angket siswa mencapai nilai 91,54 yang artinya minat dan respon siswa tinggi terhadap pembelajaran rotasi dengan menggunakan media partasi.

Setelah siswa mengisi angket, peneliti melakukan wawancara sebagai penguatan hasil angket yang dilakukan dari pukul 12.00-12.30 WIB. Subjek wawancara dalam penelitian ini adalah satu perwakilan siswa dari empat kelompok. Berdasarkan hasil wawancara, tiga dari perwakilan kelompk menyatakan jika menyukai dan senang dengan pembelajaran rotasi dengan menggunakan media partasi dikarenakan mereka lebih dapat memahami materi dan pembelajaran menjadi lebih asyik dan hidup. Adapun satu siswa menyatakan 
senang dan tertarik, namun menyatakan jika semula masih merasa canggung dikarenakan mereka belum terbiasa belajar dengan menggunakan media pembelajaran. Sehingga dari hasil wawancara ini, dapat disimpulkan pula bahwa respon siswa terhadap pembelajaran rotasi dengan menggunakan media partasi

\section{PEMBAHASAN}

Berdasarkan pada penelitian dengan menggunakan media partasi, peneliti mendapati beberapa temuan pada penelitian tersebut. Temuan yang pertama yaitu dengan adanya pembelajaran dengan menggunakan media partasi, siswa menjadi kompak dalam bekerja sama dalam kelompok dan aktif dalam diskusi. Media partasi juga membuat siswa tertarik untuk mengikuti pembelajaran matematika. Mereka dapat mengomunikasikan gagasan mereka secara lisan dan tulisan dengan teman dalam kelompok baik dua arah maupun banyak arah (Widodo, 2018). Hal ini juga sesuai dengan apa yang diungkapkan Sudjana (2002) yang mengemukakan beberapa manfaat media yaitu: (1) menumbuhkan motivasi belajar peserta didik karena pembelajaran lebih menarik, (2) makna pembelajaran menjadi lebih jelas sehingga memungkinkan terjadinya penguasaan serta pencapaian tujuan pembelajaran, (3) adanya variasi dalam metode mengajar, tidak hanya dengan komunikasi verbal; dan (4) peserta didik lebih banyak melakukan aktivitas selama kegiatan belajar, tidak hanya mendengarkan, tetapi juga mengamati, mendemonstrasikan, melakukan langsung, dan memerankan.

Keaktifan siswa selama pembelajaran dengan menggunakan media partasi ditunjukkan dengan semua indikator keaktifan yang memiliki katagori tinggi pada lembar observasi. Siswa sangat antusias untuk menggunakan media partasi dengan mencoba berbagai macam titik pada bangun untuk dirotasikan dengan berbagai sudut. Mereka mulai mengamati pola hubungan titik mula-mula dengan bayangan titik yang dihasilkan lalu menuliskannya dalam simbol matematis sehingga memperoleh rumus rotasi melalui percobaan yang dilakukan. Dapat dikatakan juga jika keberadaan media partasi ini juga membuat mereka lebih memahami konsep rotasi dan mengetahui bagaimana rumus rotasi diperoleh. Hal ini sesuai dengan apa yang diungkapkan oleh Sutiarso\&Coesamin (2018) yang menyatakan jika peranan media yang disiapkan oleh guru sangat penting dan membantu siswa dalam memahami konsep, bahkan siswa yang memiliki kesulitan belajar.

Di sisi lain, ditemukan indikator keaktifan dalam katagori sedang yakni ketika pengamatan siswa kepada teman yang melakukan presentasi. Hal ini dikarenakan waktu pembelajaran yang hampir habis mempengaruhi fokus siswa untuk memperhatikan sajian presentasi. Konsentrasi siswa pun menjadi sedikit terpecah ketika bel berbunyi tanda istirahat. Apa yang terjadi ini sangat peneliti sadari karena sesuai dengan yang diungkapkan oleh Af'ida (2018) yang menyatakan jika waktu pembelajaran berpengaruh terhadap konsentrasi belajar siswa. Selain itu, waktu belajar yang tersedia dapat mempengaruhi hasil belajar matematika (Lestari 2015).

Adapun penilaian dari sisi peneliti sebagai guru, maka peneliti merasa jika membelajarkan materi rotasi dengan media partasi ini terasa lebih mudah dan daya serap siswa dalam memahami konsep rotasi relatif cepat. Guru tidak perlu menuliskan contoh rotasi titik di papan lalu menggambarkannya satu persatu untuk didapatkan kesimpulan rumus rotasi. Guru juga tidak harus banyak ceramah 
memberikan banyak latihan soal agar siswa terbiasa mengerjakan soal rotasi agar lebih paham. Hal ini sesuai dengan (Irma, 2017) yang menyatakan jika media pembelajaran dapat membantu guru dalam memperjelas penyajian pesan supaya tidak terlalu verbalitas (dalam bentuk kata-kata tertulis atau hanya lisan) saja.

Respon siswa terhadap pembelajaran diperkuat dengan hasil angket yang disebar kepada peserta didik. Berdasarkan hasil angket yang diperoleh, siswa mengungkapkan jika mereka lebih mudah memahami matematika dengan menggunakan media partasi. Pemahaman mereka mengenai materi rotasi tidak harus dari penjelasan guru yang panjang lebar, tapi lebih didukung adanya media partasi. Hal ini sesuai dengan peranan media bahwa dapat merubah cara berbicara dalam penyampaian materi satu sama lain (Cope \& Kalantzis dalam Capuno dkk, 2019). Angket siswa juga menyatakan jika media partasi juga memiliki tampilan yang menarik dan mudah digunakan.

\section{KESIMPULAN}

Penerapan media partasi dalam pembelajaran rotasi sangat mempengaruhi keaktifan siswa dalam pembelajaran. Hal ini dibuktikan dengan data hasil pengamatan aktivitas yang dilakukan pada siswa dengan memeproleh nilai 90,93 dengan katagori keaktifan tinggi. Keaktifan itu ditunjukkan dengan siswa aktif dalam melakukan percobaan merotasikan titik dan berdiskusi hingga menemukan rumus rotasi titik.

\section{SARAN}

Guru dianjurkan menggunakan media partasi karena penggunaan media partasi ini dapat membantu siswa memahami materi pelajaran dan dapat meningkatkan keaktifan siswa dalam belajar materi rotasi. Media partasi juga mempermudah guru dalam menyampaikan materi transformasi geometri, khususnya rotasi.

\section{DAFTAR RUJUKAN}

Af'ida, Idda. 2018. Konsentrasi Belajar Ditinjau Dari Pengelolaan Kelas Dan Waktu Pembelajaran Mata Pelajaran Akuntansi Dasar Pada Siswa Kelas X Akuntansi SMK Negeri 1 Salatiga Tahun Ajaran 2017/2018. Universitas Muhammadiyah Surakarta.

Arsyad. 2005. Media Pembelajaran. Jakarta: Jakarta:PT Raja Grafindo Persada.

Capuno, Reylan et al. 2019. Facilitating Learning Mathematics Through the Use

of Instructional Media. IEJME: International Electronic Journal of Mathematics Education 14(3): 677-88.

Creswell, John W. 2012. Educational Research Planning, Conducting and Evaluating Quantitative and Qualitative Research. ed. Matthew Buchholtz.

Hamalik, Oemar. 2008. Kurikulum Dan Pembelajaran. Jakarta: Bumi Aksara.

Huda, Fatkhan Amirul. 2018. Pengertian Keaktifan Belajar. Fatkhan Web.Id.

Irma. 2017. Pentingnya Media Dan Model Pembelajaran dalam Proses Mengajar. MetroJambi.com

Kabha, Robin. 2019. Cognitive, Affective, Social and Cultural Aspects of Teaching and Learning in Media Studies. European Journal of Educational Research 8(4): 1287-94. 
Lestari, Indah. 2015. Pengaruh Waktu Belajar Dan Minat Belajar Terhadap Hasil Belajar Matematika. Formatif: Jurnal Ilmiah Pendidikan MIPA 3(2): 115-25.

Musfiqon. 2012. Pengembangan Media \& Sumber Pembelajaran. Jakarta: Prestasi Pustaka.

Purnomo, Mukhamad Suryo. 2015. Peningkatan Minat Belajar IPA Materi Struktur Bumi Melalui Media Gambar Pada Siswa Kelas V SD Negeri Ronggo Semester II Tahun Pelajaran 2014/2015. Surakarta.

Putri, Kamila, I M Candiasa, and G Suweken. 2016. Pengembangan Media Pembelajaran Transformasi Berbasis Geogebra. Wahana Matematika dan Sains 10: 25-35.

Setyorini, Dyna, and Madziatul Churiyah. 2016. Increasing Activeness and Learning Outcomes by Developing Borland Delphi 7. O Application as Instructional Media. Journal of Education and Practice 7(14): 129-40.

Sudjana, Mania, dan Ahmad Rivai. 2002. Media Pembelajaran. Bandung: Sinar Baru Algasindo.

Sudjana, N. 2010. Dasar-Dasar Proses Belajar Mengajar. Bandung: Bandung: Sinar Baru Algesindo.

Suseno, Wawan, Ipung Yuwono, and Gatot Muhsetyo. 2017. Persamaan Linear Dua Variabel Dengan Pembelajaran Kooperatif Tgt. Jurnal Pendidikan: Teori, Penelitian, dan Pengembangan 2(10): 1298-1307.

Sutiarso, Sugeng, and M Coesamin. 2018. The Effect Od Various Media SCaffolding on Inceasing Understanding of Student's Geometry Concept. Journal on Mathematics Education 9(1): 95-102.

Wibowo, Nugroho. 2016. Upaya Peningkatan Keaktifan Siswa Melalui Pembelajaran Berdasarkan Gaya Belajar Di Smk Negeri 1 Saptosari. Elinvo (Electronics, Informatics, and Vocational Education) 1(2): 128-39.

Widodo, Sri Adi. 2018. Selection of Learning Media Mathematics for Junior School Students. The Turkish Online Journal of Educational Technology 17(1): 154-60 